\title{
The Effect of Using Audiobook on Speaking Performance of Basic Education Students in Jordan
}

\author{
Ahlam Taha Salem Al.fakara \\ A Teacher of English - Ministry of Education
}

\begin{abstract}
This study aimed at investigating the effect of using audiobook on speaking performance of basic education students in Jordan. To fulfill this purpose, three instruments were constructed: a speaking skills questionnaire to determine the necessary speaking skills for tenth gradel basic stage students, a pre - post speaking test to assess EFL student speaking performance before and after the study intervention and a rubric for assessing and scoring the EFL speaking skills included in the speaking test. The validity and reliability of the study instruments were established before their application in the study. The quasi-experimental design was adopted. The participants of the study were sixteen students selected from the tenth grade/ basic stage students at The Martyr Pilot Muath Al-Kasasbeh in AL-karak Directorate, Jordan. The experimental group students were taught through the proposed audiobooks activities while the control group students studied through the regular instructional activities. Results revealed that the experimental group students EFL speaking performance was significantly enhanced. It was recommended that audiobook should be used in EFL teaching to enhance speaking skills and other language skills.
\end{abstract}

Key words: speaking skills, audiobooks

\section{Introduction}

A huge demand has been created for learning English language around the world. Today, a good command of English is very vital for millions of people, they need English language for travel, study abroad, communicate with others.etc. So people need to master English to a high level of accuracy and fluency which is a prerequisite for advancement and success in many fields. One of the demanding English language skills for EFL learners is speaking, as they need to have not only grammar and lexical knowledge, but also knowledge of sociallyappropriate language.

Ranson (2000) indicates that speaking becomes meaningful when it enables the learners to explore their selves, express their identity and enables them to understand and respect their own selves. Speaking is a collection of micro-skills; grammar, syntax, morphology, pragmatics, semantics and phonology. Mckay 
(2006) claims that when the learners have been exposed to linguistic competences as pronunciation, grammar and vocabulary, as well as to the sociolinguistic competence such as the expressions and the contextualizing of the language, they can produce effective and appropriate outcomes. Speaking is a predictable process and it has some discourse situations; inviting, requesting, offering, greeting, and introducing selves. On other hand, Torky (2006) defines speaking as an interactive process which is the involvement of another person unlike listening, reading or writing.

In spite of the importance of speaking skills for EFL learners, students face a number of difficulties that include the learners' inability to maintain spoken communication outside short fragments, misapprehensions and repeated communication cessations, lack of vocabulary and communication tactics, weak syntax and pronunciation, assessment system which lack of speaking skills assessment and classroom environment doesn't support verbal activities.

The present study used audiobook activities to improve speaking skills for basic education students in Jordan.

\section{Review of Literature}

\section{The Speaking Skill}

Florez (1999) defines
speaking skill as using
understandable and appropriate
vocabulary for the audience, and
that is appropriate to the topic
being discussed, and the setting in
which the speech act occurs.

Harmer (2007) shows that speaking process involves the following three AAA stages (awareness, appropriation and autonomy)in which the learners made aware of target language knowledge's features that are integrated into their existing knowledge-base and develop the capacity to mobilize these features under real-time conditions without assistance.Speaking is defined by Chaney and Burks (1998) as "the process of building and sharing meaning through the use of verbal and non-verbal symbols, in a variety of contexts.

Speaking is defined as an interactive process of constructing meaning that involves producing, receiving and processing information. Its form and meaning are dependent on the context in which it occurs, the participants, and the purposes of speaking (Burns \& Joyce, 1997).

Speaking is defined operationally in this study as the basic stage students' ability to 


\begin{tabular}{l}
\hline \hline \\
express themselves orally, \\
coherently, fluently and \\
appropriately in a given \\
meaningful context to serve both \\
transactional and interactional \\
purposed using correct \\
pronunciation, grammar and \\
vocabulary and adopting the \\
pragmatic and discourse rules of \\
the spoken language.
\end{tabular}

\section{Speaking Skills Strategies:}

Alcaya, et.al (1994) classify speaking strategies into three categories: (a) Pre-speaking strategies: which subdivided into strategies for lowering anxiety (relaxation), strategies for preparing and planning (purpose of speaking), and strategies for planning responses and contributions (organizing thoughts) (b) During- speaking activities as conversation and monitoring performance.(c) Post-speaking strategies which are subdivided into strategies for evaluating speaking performance and strategies for planning future tasks.

\section{Speaking activities}

In the classroom has five parameters; First, the extent of variation; no change, limited change, and free expression. Second, the extent of constraint as cue cards and symbols. Third, the extent of predictability such as formulas and information gap. Fourth, the extent and nature of interaction such as pairs and groups. Fifth, the extent of realism or personal involvement such as role-play, simulations, and personal expression (Grauberg, 2004).

Zhang (2009) also lists three activities which provide students with opportunities to practice their spoken English, each activity has its own steps. He designed each activity around a different text. Each activity is designed around a different reading text. The time was set according to the difficulty of the task and the time limits of the class as a whole. These speaking skills activities are: read to act, read to debate, and read to review.

\section{Speaking Problems:}

Students face many speaking problems as: The major one is that the learners can't maintain spoken communication outside short fragments, misapprehensions and repeated communication cessations, lack of vocabulary and communication tactics, speaking slowly, weak syntax and pronunciation, assessment system which lack of speaking assessment, classroom environment doesn't support verbal activities and the curriculum itself which ignore speaking activities and exercises (Richard, 2001). 
Principles of Teaching Speaking:

Nunan (2003) indicates some principles that may help teachers in teaching speaking skills and students in enhancing their speaking skills: First, Teachers should have knowledge to differentiate between language as a second language and as a foreign one. Second, teachers have to provide students with opportunities to practice English language with fluency and accuracy. Third, provide the learning environment with pair and group work. Fourth, Teachers should involve negotiation of meaning by speaking plan. Forth, teachers should provide both transactional and interactional speaking by involving practice within speaking activities. Finally, teachers should prompt students to speak more and more by asking.

\section{Related Studies}

Khalaf (2017) investigated the effectiveness of a suggested program based on multiple intelligences theory and WebQuests in developing AlAzhar first year secondary school students' listening and speaking skills. The study adopted the quasiexperimental pretest-posttest experimental group/control group design. Participants in the study were first year secondary school male students. The experimental group received a program to learn some listening and speaking skills through a suggested program based on multiple intelligences theory and WebQuests. The results of the study indicated that there were statistically significant differences between the experimental group and control group in listening for gist, listening for specific information, listening for details, and functional speaking, speaking for purposes, and giving oral presentation. It was concluded that the present study provided evidence for the effectiveness of using a suggested program based on multiple intelligences theory and WebQuests in developing the experimental group students' listening and speaking skills. It was recommended that teachers should motivate students to use WebQuests while learning.

Farag (2015) measured the effectiveness of a computer mediated program in improving speaking skills and motivation during 60 pupils who were selected randomly from 6 grade of Dr. Said Metwaly Primary School. The instruments of the study were constructed; a questionnaire to determine the speaking sub skills needed, a pre- post speaking skills, a rubric and a scale of motivation used before and after the treatment to measure students' motivation towards speaking EFL. The results 
revealed that the computer mediate program improve pupils' speaking skills and enhance their motivation towards the EFL speaking. The study concluded that using computer -mediate program was effective in improving pupils' performance.

Chuo \& Taiwan (2011) examined the effects of WebQuest onparticipants' language learning results in reading ability, vocabulary andspeaking. The researcher incorporated WebQuest in her course, InternetEnglish. Based on the WebQuest templates. Thirteen freshmen participated in this study. Students workedin groups and they were allowed to choose their group members. Each groupcomprised of five to six people. At the end of the project each group orallypresented their final product. Each member was given three to four minutes togive presentation. The results of the study indicated that the studentsimproved their reading ability and slightly gained vocabulary power althoughthey indicate their speaking aspect was greatly improved.

\section{Audiobooks}

The beneficial ways to use and implement audiobooks in the classroom: Teachers should bring out audiobooks at the appropriate time to give the opportunity for access to them. Also the learners must know how to use the technology as CDs and CD player, MP3 players, headphones, iPods, or computers, the he correct usage of these technology is demanded. Moreover, using the audiobook in the whole group setting to hear examples of reading fluency, intonation, and pacing. After students listen to an audiobook, teachers can lead a discussion on the efficient of a well-read book. Additionally, proving to be a wonderful resource in the classroom, listening to audiobooks can increase literacy and reading skills and using an audiobook is a fantastic way to engage students in reading, while making the reading process easier yet still beneficial for every student(Hett, 2012).

Adding a new digital dimension to class conversation enhances the home-school literacy connection by engagement families in the response process. Because it is accessible online through any computer, students and families' access to the account can listen to the books anywhere. Blogging as creating audiobook accounts for reading aloud can enable families to listen to both. They keep the student-created recordings closed to adult readers outside the classroom community (Moller \&Frguson, 2015). 
Tolba (2016), examined the effect of digital storytelling to enhance (64) preparatory stage pupils' speaking skills and their motivation towards English language. The instruments of the study were a pre-post speaking skill test and a scale to measure pupils' motivation towards English language before and after the experiment. The results of the study showed that the treatment group outperformed in the grammar skills, vocabulary and pronunciation and the treatment groups' motivation is improved and enhanced compared with the control one.

Hammam

investigates a study for developing some speaking skills of first year secondary students in Alexandria. This Quis- experimental study consists (25) first year secondary students. The researcher uses a program based on MALL to teach speaking skills to the participants. The tool of this study was pre and post speaking test which measure some sub-speaking skills (comprehension, pronunciation, fluency, grammar and vocabulary). The results of this study shows that there are significant differences in participants' achievement in favor of the experimental group.

Ab Rashid, et. al, (2017) examined ICT in education through the innovation of an interactive audio-based application as a tool to enhance English language speaking skills among less proficient students. The application named 'V-Buddy' has been developed and tested. The results showed that all the students developed higher confidence level after their engagement with $\mathrm{V}$ Buddy and the teacher perceived it positively which suggests its potential to be used as a tool in developing speaking skills among less proficient students. And the interactive nature of this application enables the students to practice and improve their speaking skills. In addition, the use of computer-assisted language learning created an enjoyable learning experience. The study concluded that future research can perhaps compare two groups of students with two different teachers to investigate the effects of different ways of facilitating the students on the efficiency of interactive audio-based application, such as V-Buddy.

In the light of the findings of related studies mentioned above in this section, the following can be highlighted:

- Speaking is vital means to provide communication among human beings.

- The previous studies such as (Tolba, 2016; Hammam, 2017 
and Ab Rashid, et. al, 2017) were in agreement with the current study in the importance of developing speaking skill among the students.

Teaching English language learners through technology explores the use of computers and technology as pedagogical tools to be selected and used in the appropriate instruction of English language by learners EFLs across all areas (Erben, Ban \& Castaneda, 2004).

Technology development has changed not only the way classroom appear, but also necessitates a change in how students in the classrooms learn. However a problem continues to exit related to teachers using technology in meaningful ways for instruction. Teacher should understand the benefit of technology in teaching and learning and find meaningful ways of technology integration in teaching (Liu, 2005).

\section{Advantages of using audiobooks}

Listening to audiobooks increases and enhances such literacy skills as vocabulary, fluency, and comprehension for both accomplished and struggling readers, as well as Englishlanguage learners. Audiobooks offer a unique opportunity to share stories in a way that not only increases comprehension but also heightens enjoyment. $\mathrm{He}$ has advised many parents on the benefits of audiobooks in their child's literacy development (Burkey, 2013).

Serafini (2004) offers several reasons why teachers and parents are encouraged to use audiobooks; Allow reader to know new vocabulary which become part of a child's oral and eventually written vocabularies, provide the reader with fluent reading and appropriate phrasing, intonation, and articulation, access to materials for readers: Experienced readers and those struggling with decoding can listen to stories well beyond their independent reading levels and comprehend more complex literature, create opportunities for readers to discuss literature through which reading comprehension is enhanced through discussion, and audiobooks provide a perfect opportunity for classes to share these stories, invite children into the world of reading and literature. One of the most important roles of classroom teachers and librarians is exposing children to quality literature and support struggling readers as developing readers listen to audiobooks and follow along with a printed version of the story, they learn to match the sounds of oral language to their 
written counterparts. This matching of sounds to symbols is the basis for reading instruction.

\section{Audiobook Formats}

Audiobooks have several formats such as records, cassette tapes, CDs, MP3 players, and online books, they can also be found in a variety of places online to listen to through the computer while following along with the text on the screen, or to purchase and download. They are rising in popularity due to so many people being connected to their iPods, cell phones, or MP3 players, they became the most popular collections in many libraries (Hett, 2012).

\section{Audiobook as an Educational Tool:}

Teachers should use and implement compensatory strategies to facilitate learning, avoid downgrading the intellectual skills and preserve students' self-esteem. One of the most of these recommended strategies is using a recorder and tapes (recorded by teachers, pupils and/or tapes attached to books) or synthesizers in order to read scanned texts. Another frequently issued recommendation is that an archive containing the recordings of the adopted book list and other culturally relevant books should be set up in every school. Teachers should use and implement compensatory strategies to facilitate learning, avoid downgrading the intellectual skills and preserve students' self-esteem. One of the most of these recommended strategies is using a recorder and tapes (recorded by teachers, pupils and/or tapes attached to books) or synthesizers in order to read scanned texts (Milani, et. al., 2009).

\section{Audiobooks in Classroom:}

Audiobooks make literature as a phenomenon to be enjoyed than a puzzle to be solved. They are a fresh chance to find way to books, and to hold onto them (Varely, 2002).

Bringing the audiobook into the classroom becomes very simple and inexpensive with the availability of iPods and similar audio devices. There are many advantages of using audiobooks as improving fluency, expand vocabulary, activate prior knowledge, develop comprehension, and increase motivation to interact with books. Also audiobooks remove the restraints of word recognition and decoding allows a very positive focus on the meaning behind an author's words. Furthermore, they provide opportunity for many students, including those with special needs, to experience the 
same books as the other students. Additionally, they develop literacy skills before, during, or after listening. Specific skills that can be demonstrated include recalling details, understanding sequence, making predictions, drawing conclusions, making inferences, and retelling. Moreover, audiobooks present opportunities to develop comprehension skills and strategies in critical and creative thinking for proficient readers (Wolfson, 2008).

\section{The pilot study:}

A pilot study was conducted to assess the students' current level in EFL speaking skills. A selected sample was taken from Al.Marj Basic School for girls in Al-Karak Directorate, Jordan to check the students' speaking performance in the first midterm exam 2017. The sample included 30 girls. The following table shows the mean score and the percentage of speaking section in the English language test.

Table (1)

The analysis of the results of the pilot study test

\begin{tabular}{|l|c|c|c|c|}
\hline \multicolumn{1}{|c|}{ Speaking skill } & Mean & Std. Deviation & $\begin{array}{c}\text { The Highest } \\
\text { Grade }\end{array}$ & $\begin{array}{c}\text { Passing } \\
\text { Grade }\end{array}$ \\
\hline Fluency & 1.98 & 1.18 & 4 & 2 \\
\hline Vocabulary & 1.70 & 1.20 & 4 & 2 \\
\hline Pronunciation & 1.63 & 1.03 & 4 & 2 \\
\hline Organizing information & 1.63 & .89 & 4 & 2 \\
\hline Grammar & 1.80 & .92 & 4 & 2 \\
\hline \multicolumn{1}{|c|}{ Total } & 8.75 & 4.77 & 20 & 10 \\
\hline
\end{tabular}

It has been observed that the level of students in overall speaking skills is below the desired and required average. Additionally, the five sub skills have a statistical averages of (8.75). To further elaborate, these averages are as follows: 1.98 , $1.70,1.63,1.63$, and 1.80.This showed that students lacked the necessary skills to communicate and practice English as a foreign language. Therefore, it was essential to tackle this problem and find a proper remedy in order to provide the learners with the basic skills to deal with speaking skills and communicate with others properly. Therefore, the researcher suggested using an audiobook to enhance Jordanian basic education students' speaking skills. 


\section{Statement of the Problem}

Based on the researchers experience as a teacher of EFL and on the results of the pilot study, the problem of the current study can be stated as follows: Jordanian EFL basic schools students have difficulties in speaking skills such asmisapprehensions and repeated communication cessations, lack of vocabulary and communication tactics, weak syntax and pronunciation, assessment system which lack of speaking skills assessment and classroom environment doesn't support verbal activities.

This study proposed the use of audiobook activities to help students improve their speaking skills.

\section{Questions of the Study:}

What is the effectiveness of using audiobook activities indeveloping EFL basic stage students' speaking skills?

For research purposes, the following sub-questions were derived from the main question:

1. What are speaking sub-skills that basic stage students should master?

2. What are the characteristics of audiobook activities for developing these sub-skills?

\section{Purpose of the Study:}

The present study aims at:

1. Developing speaking skills of basic stage students.

2. Identifying speaking skills and sub-skills necessary for basic stage students.

3. Identifying the features of audiobook activities suitable for developing these subskills,

4. Measuring the effectiveness of using audiobooks activities in developing EFL basic stage students' speaking skills.

\section{Hypotheses of the Study}

The study hypothesized that

1. There is a significant difference at 0.05 level between the mean score of the experimental group students on the pre - post administration of the speaking test in favor of the post one.

2. There is a significant difference at 0.05 level between the mean score of the control group and the experimental group on the post administration of the speaking test in favor of the experimental group.

\section{Method}

\section{Design:}

The study adopted the quaisexperimental design using one group (experimental group). Both 
groups (experimental and control groups) received the pre- post speaking test assess the target speaking skills.

\section{Participants:}

The participants was one experimental group of tenth grade students from The Martyr Pilot Muath Al-Kasasbeh Secondary School for Boys in Al-Karak Directorate, Jordan. One class will be assigned as the experimental group that studied using audiobook. Participants were divided into two groups: one control and one experimental, and each group consisted of 30 students. The experimental group students were taught through audiobook while the control group students studied through the regular instructions and activities planned by the ministry of education in Jordan.

\section{Instruments:}

The following instruments were designed and used in:

1. A list of speaking skills necessary for EFL basic stage students for determining the speaking skills that should be mastered by EFL basic stage students.

2. A pre- post speaking skills test for assessing the speaking skills for EFL basic stage students.

3. A rubric for assessing and scoring the EFL speaking skills included in the speaking test.

\section{Results and discussions}

Results were statistically analyzed in terms of the study hypotheses. They were discussed in the light of the theoretical background and related studies. Results were reported as follows:

\section{Testing the first hypothesis:}

The first hypothesis stated that there is a significant difference at 0.05 level between the mean score of the experimental group students on the pre - post administration of the speaking test in favor of the post one ".

In order to validate this hypothesis, the researcher used ttest. 


\section{Table (2)}

$T$-Test of the experimental group on the pre -post administration of the EFL speaking test

\begin{tabular}{|c|c|c|c|c|c|c|c|c|c|}
\hline Skills & Test & $\mathbf{N}$ & Mean & $\begin{array}{c}\text { Mean } \\
\text { paired } \\
\text { differences }\end{array}$ & $\begin{array}{c}\text { Std. } \\
\text { Deviation }\end{array}$ & $\begin{array}{c}\text { Std. } \\
\text { Deviation } \\
\text { paired } \\
\text { differences }\end{array}$ & df & $\mathbf{t}$ & Sig \\
\hline \multirow{2}{*}{$\begin{array}{l}\text { first } \\
\text { skill }\end{array}$} & Pre-test & 30 & 0.50 & \multirow{2}{*}{1.42} & 1.017 & \multirow{2}{*}{1.565} & \multirow{2}{*}{29} & \multirow{2}{*}{4.958} & \multirow[t]{2}{*}{0.01} \\
\hline & Post- test & 30 & 1.92 & & 1.075 & & & & \\
\hline \multirow{2}{*}{$\begin{array}{l}\text { Second } \\
\text { skill }\end{array}$} & Pre-test & 30 & 0.50 & \multirow{2}{*}{1.75} & 1.017 & \multirow{2}{*}{1.165} & \multirow{2}{*}{29} & \multirow{2}{*}{8.226} & \multirow[t]{2}{*}{0.01} \\
\hline & Post- test & 30 & 2.25 & & 0.763 & & & & \\
\hline \multirow{2}{*}{$\begin{array}{c}\text { Third } \\
\text { skill }\end{array}$} & Pre-test & 30 & 0.17 & \multirow{2}{*}{1.83} & 0.634 & \multirow{2}{*}{1.124} & \multirow{2}{*}{29} & \multirow{2}{*}{8.930} & \multirow[t]{2}{*}{0.01} \\
\hline & Post- test & 30 & 2.00 & & 1.017 & & & & \\
\hline \multirow{2}{*}{$\begin{array}{c}\text { Fourth } \\
\text { skill }\end{array}$} & Pre-test & 30 & 0.33 & \multirow{2}{*}{1.92} & 0.864 & \multirow{2}{*}{1.075} & \multirow{2}{*}{29} & \multirow{2}{*}{9.761} & \multirow[t]{2}{*}{0.01} \\
\hline & Post- test & 30 & 2.25 & & & & & & \\
\hline \multirow{2}{*}{$\begin{array}{l}\text { Fifth } \\
\text { skill }\end{array}$} & Pre-test & 30 & 0.58 & \multirow{2}{*}{1.58} & 0.763 & \multirow{2}{*}{1.390} & \multirow{2}{*}{29} & \multirow{2}{*}{6.238} & \multirow[t]{2}{*}{0.01} \\
\hline & Post- test & 30 & 2.17 & & 1.075 & & & & \\
\hline \multirow{2}{*}{$\begin{array}{l}\text { sixth } \\
\text { skill }\end{array}$} & Pre-test & 30 & 0.83 & \multirow{2}{*}{1.41} & 0.864 & \multirow{2}{*}{1.697} & \multirow{2}{*}{29} & \multirow{2}{*}{4.572} & 0.01 \\
\hline & Post- test & 30 & 2.25 & & 1.199 & & & & \\
\hline seventh & Pre-test & 30 & 0.58 & 150 & 0.763 & 140 & 20 & 58 & 0.01 \\
\hline skill & Post- test & 30 & 2.08 & 1.50 & 1.075 & 1.400 & 29 & 5.055 & \\
\hline Eighth & Pre-test & 30 & 0.75 & 117 & 1.165 & & & & 0.01 \\
\hline skill & Post- test & 30 & 1.92 & 1.17 & 1.075 & 1.428 & 29 & $4.4 / 4$ & \\
\hline Total & Pre-test & 30 & 4.25 & & 5.092 & & & & 0.01 \\
\hline skills & Post- test & 30 & 16.83 & 12.58 & 2.361 & 4.890 & 29 & 14.094 & \\
\hline
\end{tabular}

Comparing the mean scores in the pre- post administration of the speaking test reveal that the experimental group students'meanscore in the overall pre speaking test is (4.25), whereas their mean score in the overall post speaking test is (16.83). These values indicated the significant difference between the mean scores before and after the administration of the speaking test in favor of the post one.

The greater mean score of the experimental group's post test implies that the experimental group students' level in overall speaking was enhanced due to using the audiobook. This increase indicates the effect of this program. 
Testing the second hypothesis:

The second hypothesis stated that there is a significant difference at 0.01level between the mean score of the control group and the experimental group on the post administration of the speaking test in favor of the experimental group.

In order to validate this hypothesis, the research used t-test is presented in the following table:

Table (3)

$T$ - Test of the control and experimental groups on the post administration of the EFL speaking test.

\begin{tabular}{|c|c|c|c|c|c|c|c|}
\hline Skills & group & $\mathbf{N}$ & Mean & $\begin{array}{c}\text { Std. } \\
\text { Deviation }\end{array}$ & df & $\mathbf{t}$ & Sig \\
\hline \multirow{2}{*}{ first skill } & experimental group & 30 & 1.92 & 1.075 & \multirow{2}{*}{58} & \multirow{2}{*}{3.051} & \multirow{2}{*}{0.01} \\
\hline & control group & 30 & 1.00 & 1.246 & & & \\
\hline \multirow{2}{*}{$\begin{array}{c}\text { Second } \\
\text { skill }\end{array}$} & experimental group & 30 & 2.25 & 0.763 & \multirow{2}{*}{58} & \multirow{2}{*}{6.382} & \multirow{2}{*}{0.01} \\
\hline & control group & 30 & 0.67 & 1.124 & & & \\
\hline \multirow{2}{*}{$\begin{array}{l}\text { Third } \\
\text { skill }\end{array}$} & experimental group & 30 & 2.00 & 1.017 & \multirow{2}{*}{58} & \multirow{2}{*}{5.712} & \multirow{2}{*}{0.01} \\
\hline & control group & 30 & 0.50 & 1.017 & & & \\
\hline \multirow{2}{*}{$\begin{array}{c}\text { Fourth } \\
\text { skill }\end{array}$} & experimental group & 30 & 2.25 & 0.763 & \multirow{2}{*}{58} & \multirow{2}{*}{4.687} & \multirow{2}{*}{0.01} \\
\hline & control group & 30 & 1.00 & 1.246 & & & \\
\hline \multirow{2}{*}{$\begin{array}{c}\text { Fifth } \\
\text { skill }\end{array}$} & experimental group & 30 & 2.17 & 0.864 & \multirow{2}{*}{58} & \multirow{2}{*}{5.793} & \multirow{2}{*}{0.01} \\
\hline & control group & 30 & 0.67 & 1.124 & & & \\
\hline \multirow{2}{*}{$\begin{array}{l}\text { sixth } \\
\text { skill }\end{array}$} & experimental group & 30 & 2.25 & 0.763 & \multirow{2}{*}{58} & \multirow{2}{*}{4.687} & \multirow{2}{*}{0.01} \\
\hline & control group & 30 & 1.00 & 1.246 & & & \\
\hline \multirow{2}{*}{$\begin{array}{c}\text { seventh } \\
\text { skill }\end{array}$} & experimental group & 30 & 2.08 & 0.948 & \multirow{2}{*}{58} & \multirow{2}{*}{5.732} & \multirow{2}{*}{0.01} \\
\hline & control group & 30 & 0.58 & 1.075 & & & \\
\hline \multirow{2}{*}{$\begin{array}{c}\text { Eighth } \\
\text { skill }\end{array}$} & experimental group & 30 & 1.92 & 1.075 & \multirow{2}{*}{58} & \multirow{2}{*}{3.360} & \multirow{2}{*}{0.01} \\
\hline & control group & 30 & 0.92 & 1.225 & & & \\
\hline \multirow{2}{*}{$\begin{array}{l}\text { Total } \\
\text { skills }\end{array}$} & experimental group & 30 & 16.83 & 2.361 & \multirow{2}{*}{58} & \multirow{2}{*}{12.071} & \multirow{2}{*}{0.01} \\
\hline & control group & 30 & 6.33 & 4.138 & & & \\
\hline
\end{tabular}

in favor of the experimental one. These differences were due to using the audiobook program. Thus, the experimental group students exceeded their mates of the control group who studied through the regular activities
Results in table (3) showed that there was a statistically significant difference between the mean score of the control and experimental groups students' at (0.01) level in the post administration of the speaking test 
calculating the t-value. The formula was:

$$
\eta 2=\frac{t_{2}}{t 2+d f}
$$

The following table illustrates the effect size of the proposed audiobook on the experimental group students' speakingskills. planned by the Ministry of Education.

\section{The Effect size of the proposed activities:}

First, eta square ( $\eta 2)$ was estimated to calculate the effect size of the proposed audiobook on the students' speaking skills. Eta square ( $\eta 2)$ was estimated after

Table (4)

Value of ( $\eta 2)$ and the Level of Effect Size

\begin{tabular}{|c|c|c|c|c|c|c|c|}
\hline $\begin{array}{c}\text { The } \\
\text { Independ } \\
\text { ent } \\
\text { Variable }\end{array}$ & $\begin{array}{c}\text { The } \\
\text { Dependent } \\
\text { Variable } \\
\text { Speaking } \\
\text { Skills }\end{array}$ & $\mathbf{t}$ & $\mathbf{t}^{2}$ & $\mathbf{t}^{2}+\mathbf{d f}$ & $\boldsymbol{\eta}^{2}$ & $\begin{array}{c}\text { The } \\
\text { Effective } \\
\text { Size }\end{array}$ & $\begin{array}{c}\text { The } \\
\text { Effective }\end{array}$ \\
\hline \multirow{7}{*}{$\begin{array}{c}\text { Audio } \\
\text { book }\end{array}$} & first skill & 3.051 & 9.31 & 67.31 & 0.14 & $14 \%$ & high \\
\cline { 2 - 8 } & Second skill & 6.382 & 40.73 & 98.73 & 0.41 & $41 \%$ & high \\
\cline { 2 - 8 } & Third skill & 5.712 & 32.63 & 90.63 & 0.36 & $36 \%$ & high \\
\cline { 2 - 8 } & Fourth skill & 4.687 & 21.97 & 79.97 & 0.27 & $27 \%$ & high \\
\cline { 2 - 8 } & Fifth skill & 5.793 & 33.56 & 91.56 & 0.37 & $37 \%$ & high \\
\cline { 2 - 8 } & Sixth skill & 4.687 & 21.97 & 79.97 & 0.27 & $27 \%$ & high \\
\cline { 2 - 8 } & Seventh skill & 5.732 & 32.86 & 90.86 & 0.36 & $36 \%$ & high \\
\cline { 2 - 8 } & Eighth skill & 3.360 & 11.29 & 69.29 & 0.16 & $16 \%$ & high \\
\cline { 2 - 8 } & Total skills & 12.071 & 145.71 & 203.71 & 0.72 & $72 \%$ & high \\
\hline
\end{tabular}

Results in table (4) illustrate the eta square for each speaking sub-skill. The effect size values are $(0.14,0.41,0.36,0.27,0.37,0.27$. 0.36 and 0.16 respectively). It is obvious that the total of these values is (0.72) and all of these values exceeded (0.37) which reflects a high effect size for all the target speaking skills.
The effect size ranged between (0.14and 0.41) for the target speaking skills which points to the high impact of the experimental treatment in this study. Thus, it can be assumed that theaudiobook activities enhanced EFL basic stage students' speaking skills significantly.

To sum up, all the values of eta square $(\eta 2)$ mentioned in table 
(4) are higher than (0.37) which show the great effect of the audiobookactiviteson improving EFL basic stage students' speaking skills.

\section{Discussion of Results:}

According to the tables presented above, the present study reached the

following results:

1. There is a significant difference at 0.05 level between the mean score of the experimental group students on the pre - post administration of the speaking test in favor of the post one.

2. There is a significant difference at 0.05 level between the mean score of the control group and the experimental group on the post administration of the speaking test in favor of the experimental group.

These results are congruent with the results of the previous studies in the field of EFL such as Khalaf (2017) who investigated the effectiveness of a suggested program based on multiple intelligences theory and WebQuests in developing AlAzhar first year secondary school students' listening and speaking skills, Farag (2015) who measured the effectiveness of a computer mediated program in improving speaking skills and motivation and Chuo \& Taiwan, (2011) who examined the effects of WebQuest on participants' language learning results in reading ability, vocabulary and speaking.

The study results are congruent with the studies that investigated audio program and speaking skill such as Tolba (2016) who found that that the treatment group outperformed in the grammar skills, vocabulary and pronunciation and the treatment groups' motivation is improved and enhanced by using the digital storytelling. The results of this study are also in agreement with Hammam(2017) who showed that some speaking skills of first year secondary students in Alexandria,were enhanced by using a program based on MALL. The findings of this study are also congruent with Ab Rashid, et. al, (2017) who indicated that all the students developed higher confidence level after their engagement with V-Buddy, an audio program, and the teacher perceived it positively which suggests its potential to be used as a tool in developing speaking skills among less proficient students. And the interactive nature of this application enables the students to practice and improve their speaking skills. 
The present study revealed that the effect size of audiobook programon students' speaking performance was large as the students of the experimental group outperformed those of the control group on post application. These results are congruent with literature findings (Tolba, 2016; Ab Rashid, et. Al, , 2017 and Hammam, 2017 ) which implied that traditional learning environments do not prepare students for the high degree of performance.

Based on the experiment and its findings, audiobook activities enhanced students' speaking skills in terms that they integrated new concepts or information into their established knowledge structures (schema). The proposed program also used integrated language learning in terms that students had to listen, then speak. In addition, audiobook engaged learners' interest ,encouraged critical thinking and supported cooperative learning.

These positive findings and significant differences between the control and experimental group might be due to the efficiency of the audiobook program. The design of this program had certain features that helped the experimental group do well on the post application of the pre posttests of speaking. First, using peer- learning helps learners to correct each other's mistakes by exchanging their own information. Second, using the audiobook as a teaching technique for the first time in Jordan to teach speaking skills was a big challenge for the researcher. Finally, using the audiobook made students depend on themselves and cooperate together in addition to being aware of what they should do during their learning.

\section{Conclusion}

This study concluded that using audiobook activities can improve Jordanian basic education students' speaking skills.

\section{Recommendations}

Based on the previous results, the present study recommends the following:

1. Examining the effectiveness of audiobooks on EFL classes to improve EFL other language skills such as listening.

2. Examining the effect of audiobook on EFL learners' motivation towards other language skills such as listening.

3. Further research should be conducted to determine the effectiveness of audiobook on other school levels. 


\begin{tabular}{lllll}
\hline \hline $\begin{array}{l}\text { Suggestions } \\
\text { Research }\end{array}$ & for & Further & $\begin{array}{l}\text { Language } \\
\text { Research. }\end{array}$ & Teaching and
\end{tabular}

The following suggestions can be considered for further research:

1. Investigating the effectiveness of audiobooks in EFL classes to improve EFL other language skills such as reading or listening.

2. Further research should be conducted to determine the effectiveness of audiobook on other school levels.

\section{References}

Ab Rashid,R. Mohamed, M.Rahman, M \& Shamsuddin. S. (2017). Developing speaking skills using virtual speaking buddy. IJET, 12(5), 195-201.

Alcaya, C., Lybeck, K., \& Mougel, P. (1994).Speaking strategies: A list compiled by teachers in the experimental sections of the speaking strategies experiment. Unpublished document, National Language Resource Center, University of Minnesota, Minneapolis.

Burkey, M. (2013). Voices in my head: Audiobooks and common core. American Library Association.

Burns, A \& Joyce, H. (1997). Focus on speaking. Sydney: National center for English

Chaney, A., \& Burk, T. (1998). Teaching oral communication in Grades K-8Erben, T., Ban, R., \& Castanda, M. Teaching English Language learners through technology. Routledge. Taylor and Francis Group, New York, NY.

Chuo, C-H. \& Taiwan, H. (2011). "An Inquiry into the Effects of Incorporating

WebQuest in an EFL College Course," IEEE, 2011. Retrieved at Chuo, Tun-Whei (2007) "The Effects of the WebQuest Writing Instruction Program on EFL Learners' Writing Performance, Writing Apprehension, and Perception," TESL-EJ, 11(3), 1 $-27$.

Florez, M. (1999). Improving adult English Language learners' speaking skills. ERIC Diget.

Grauberg, W. (2004). The elements of foreign language teaching. By Michael Grenfell Modern Languages in Practice7.4th Edition.Routledge

Hamamm, D. (2017). A mobile assisted language learning Program (MALL) for developing some speaking skills of first year secondary school students in Alexandria. 
Unpublished M.A. Thesis, Alexandria University, Egypt.

Harmer, J. (2007).How to teach speaking. New York: Edinburg Gate.

Hett, K. (2012). Technologysupported literacy in the Classroom: Using Audiobooks and digital storytelling to enhance literacy instruction. Illinois Reading Council Journal, 40 (3), 3-13.

Khalaf, M. (2017) The Effectiveness of Using a Suggested Program Based on

WebQuests and Multiple Intelligences Theory in Developing Secondary

Stage Students' English Listening and Speaking Skills. An unpublishedPhD Diss., Faculty of Education, Assiut University.

Liu,Z.(2005).Readingbehaviorinth edigitalenvironmentchangesinr eading behavior over thepast ten years. In $\mathrm{P}$, McKay. (2006).Assessing young language learners. Ernst Klett Sprachen.

Milani,A., Lorusso, L.\& Molteni, M. (2009). The effects of Audiobooks on the Psychosocial adjustment of Pre-adolescents and adolescents with Dyslexia. Published online 1 September 2009 in Wiley Inter Science.
John Wiley \& Sons, Ltd. DYSLEXIA 16: 87-97 (2010).

Moller, K\& Frguson, L. (2015). Apps in literature-based classroom instruction: Integrating reading and response through traditional and digital media. Journal of Children's Literature, 41(1), 54-60.

Nunan, D. (2003). The impact of English as a global language on educational policies and practices in the Asia-Pacific Region. TESOL quarterly, 37(4), 589-613.

Ranson, S. (2000). Recognizing the pedagogy of voice in a learning community. Educational Management \& Administration, 28(3), 263279.

Richards, J. C., \& Rodgers, T. S. (2001). Approaches and methods in language teaching (2nd Ed.). Cambridge: Cambridge University press.

Serafini, F. (2004). Audiobooks \& literacy: An educator's guide to utilizing Audiobooks in the classroom. New York: Listening Library.

Tolba, S. (2016). Utilizing storytelling to improve Preparatory stage pupils' speaking skills and motivation. Unpublished M.A. Thesis. Mansoura University, Egypt. 


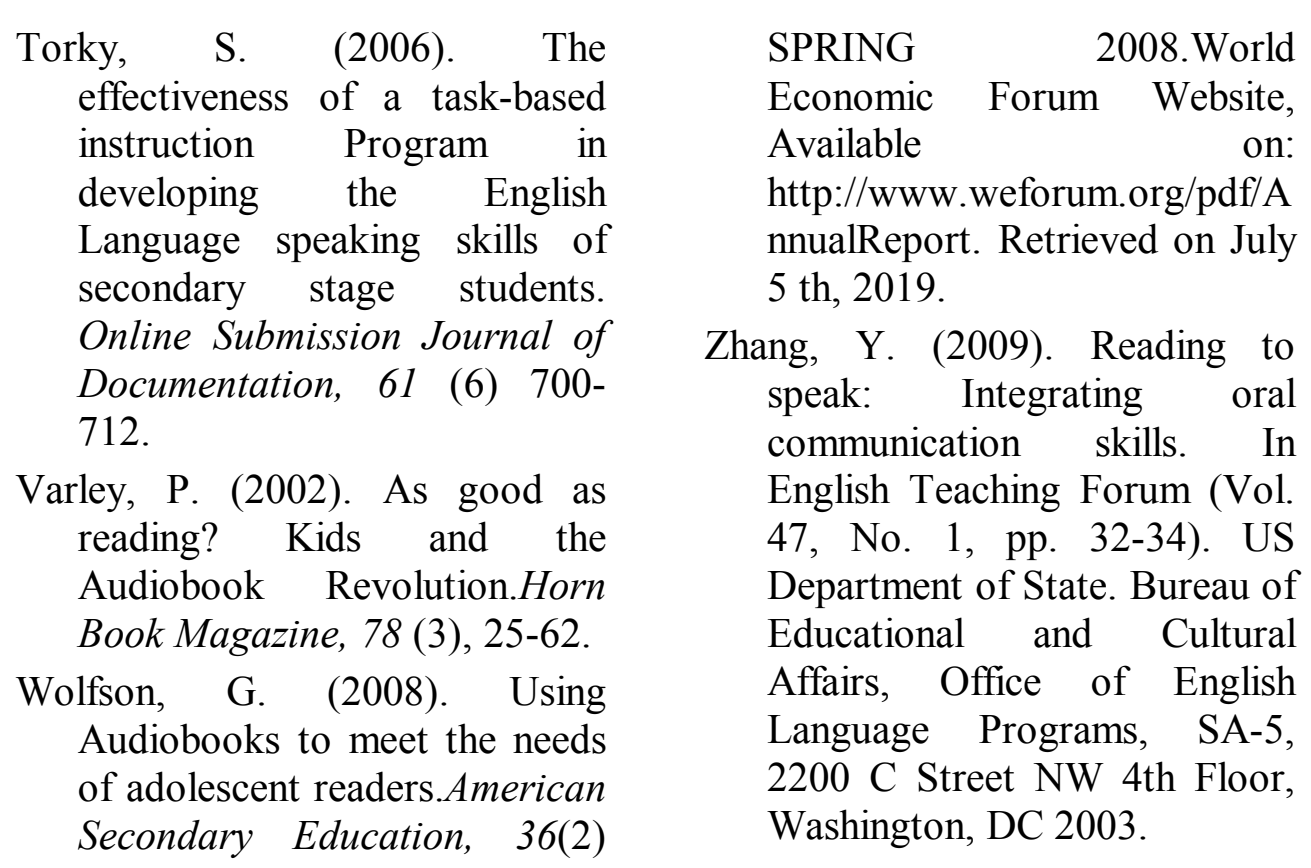

